\title{
THE SIGNIFICANCE OF BLOOD AND CEREBROSPINAL FLUID UREA LEVELS ESTIMATED AFTER DEATH
}

\author{
BY \\ W. J. JENKINS \\ From the Department of Pathology and Bacteriology, Welsh National School of Medicine, Cardiff
}

(RECEIVED FOR PUBLICATION OCTOBER 4, 1952)

Doubt exists regarding the significance and diagnostic value of raised urea levels found in blood and cerebrospinal fluid after death. Harrison (1947), for instance, considers that in the present state of knowledge of post-mortem chemistry such estimations are without value, as high results are often obtained in moribund patients without kidney disease, and he also suggested that post-mortem changes occur which might influence the urea level. Some workers found post-mortem blood and C.S.F. urea estimations of limited value (Polayes, Hershey, and Lederer, 1930 ; Hamilton, 1938 ; Naumann, 1949, 1950 ; Tarsitano, 1950), but none of them attempted to determine by repeated estimations the degree of change in the blood urea level during the important agonal period.

It may be of value when considering a cause of death to know whether a high post-mortem urea level represents an agonal rise, a post-mortem change, or urea retention during life with or without renal damage.

This paper concerns the relationship of the pre-agonal and agonal blood urea levels to the post-mortem blood and C.S.F. levels, and an interpretation of the results in the light of the clinical and full post-mortem findings. The conclusion reached is that post-mortem urea levels, particularly those in C.S.F., are of value in diagnosis.

\section{Material}

Thirty-eight cases were investigated. Most of them came from the wards of a general hospital, and many of these were studied during life, up to and including the moment of death. Further study was then made at necropsy. Other cases came to post-mortem examination via the coroner, and full details of previous health and mode of death were available.

Cerebrospinal fluid was obtained after removal of the brain by inserting a Pasteur pipette through the infundibulum into the third ventricle and applying gentle suction. In two cases a succession of post-mortem samples of C.S.F. was obtained by cisternal puncture followed by the usual sample from the third ventricle later.

In 17 instances a sample of blood was also removed from the right ventricle of the heart at the time of necropsy, and the urea content esti- $\vec{c}$ mated. On 12 occasions arm vein samples of $\omega$ blood were taken for urea estimation within the first few minutes after death.

\section{Methods}

All urea estimations were performed by the urease-nesslerization technique using a Klett colorimeter. Samples of blood and C.S.F. were refrigerated until the test could be performed, which was always within 24 hours of the time of collection.

\section{Results}

The cases are divided into four groups. The first is a control group of six sudden deaths in $\delta$ apparently healthy persons. The second consists of 19 cases of uraemia. The third is composed of 0 nine instances of pre-renal urea retention. The fourth is a miscellaneous group of four cases.

Group 1 : Sudden Death in Presumed Nonazotaemic Individuals. - In order to ascertain $\sigma$ whether a normal C.S.F. urea level alters appre- $N$ ciably after death, six cases of sudden death were స్心 investigated in which, on clinical and pathological evidence, normal ante-mortem levels could con- 0 fidently be inferred. Two were the result of road $\stackrel{D}{\Phi}$ accidents, three were due to coronary occlusion, $\stackrel{\oplus}{\rightarrow}$ and one was a homicidal cut throat.

Some of the cadavers were examined in the summer and some in the winter, and none of them had been placed in a refrigerator until at least eight hours after death.

The urea levels found in the C.S.F. in these cases were $50,33,34,38,36$, and $22 \mathrm{mg}$. per 100 
ml. respectively at times from 19 to 72 hours after death. All these figures were normal for the respective ages.

Group 2 : Renal Uraemia.-This group consists of 19 cases where uraemia from kidney disease had been given as a cause of death by other observers on clinical and pathological grounds.

From Table I it will be seen that the postmortem C.S.F. urea levels agreed well with the ante-mortem blood levels where the latter had been estimated within three days of death. The post-

TABLE I

UREA LEVELS (MG. PER 100 ML.) IN RENAL URAEMIA

\begin{tabular}{|c|c|c|c|c|c|}
\hline \multirow[b]{2}{*}{$\begin{array}{c}\text { Case } \\
\text { No. }\end{array}$} & \multirow{2}{*}{$\begin{array}{l}\text { Ante- } \\
\text { mortem } \\
\text { Blood }\end{array}$} & \multirow[b]{2}{*}{ 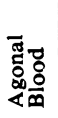 } & \multicolumn{2}{|c|}{ Post-mortem Level } & \multirow[b]{2}{*}{ Cause of Death } \\
\hline & & & $\frac{\overline{0}}{0}$ & C.S.F. & \\
\hline 7 & 325 ( 3 days $)^{*}$ & - & 一 & $290(24$ hrs. $)+$ & $\begin{array}{l}\text { Amyloid spleen and } \\
\text { kidneys with T. B. } \\
\text { of lung. and in- } \\
\text { testine }\end{array}$ \\
\hline 8 & 235 (3 dä) & - & - & $360(60,)$, & $\begin{array}{l}\text { Chronic pyelo- } \\
\text { nephritis in a sole } \\
\text { kidney }\end{array}$ \\
\hline 9 & $\begin{array}{ll}392 & \text { (4 days) } \\
512 & (1 \text { day })\end{array}$ & - & 一 & $390(72,, \quad)$ & $\begin{array}{l}\text { Chronic glomeru- } \\
\text { lonephritis }\end{array}$ \\
\hline 10 & 178 ( 2 days) & 242 & 296 & $238(13,)$, & $\begin{array}{l}\text { Cardiac failure and } \\
\text { acute nephritis }\end{array}$ \\
\hline 11 & 375 (1 day) & - & - & $400(48,, \quad)$ & $\underset{\text { Malignant }}{\text { tension }}$ hyper- \\
\hline 12 & 173 (10 days) & - & - & $400(96,, \quad)$ & Pyelonephritis \\
\hline 13 & 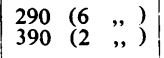 & - & - & $323(48,, \quad)$ & $\begin{array}{l}\text { Chronic } \\
\text { pyelonephritis }\end{array}$ \\
\hline 14 & 490 (3 hrs $)$ & 560 & 600 & $570(21,, \quad)$ & $\begin{array}{l}\text { Chronic glomeru- } \\
\text { lonephritis }\end{array}$ \\
\hline 15 & $\begin{array}{ll}395 & \text { (5 days) } \\
720 & (2 \quad,,)\end{array}$ & - & 一 & $880(38,, \quad)$ & $\begin{array}{l}\text { Chronic glomeru- } \\
\text { lonephritis }\end{array}$ \\
\hline 16 & $466(6 \quad, \quad)$ & - & 520 & $440(9,, \quad)$ & $\begin{array}{l}\text { Diabetic glomeru- } \\
\text { losclerosis }\end{array}$ \\
\hline 17 & 560 (9 hrs.) & - & 540 & $450(14,,)$, & Hydronephrosis \\
\hline 18 & 736 (1 day) & 924 & - & $900(20,)$, & $\begin{array}{l}\text { Chronic } \\
\text { pyelonephritis }\end{array}$ \\
\hline 19 & $\begin{array}{l}261 \text { (3 days) } \\
371 \text { (15 hrs.) }\end{array}$ & - & 378 & $350(13,)$, & Pyelonephritis \\
\hline 20 & $\begin{array}{l}412 \text { (1 day) } \\
410 \text { (10 hrs. })\end{array}$ & 400 & $\overline{\overline{4}}$ & $\begin{array}{l}395(13,,,) \\
393(17,, \quad) \\
438(37,, \quad)\end{array}$ & $\begin{array}{l}\text { Chronic } \\
\text { glomerulo- } \\
\text { nephritis }\end{array}$ \\
\hline 21 & 210 (3 days) & 390 & 394 & $344(20,, \quad)$ & Hydronephrosis \\
\hline 22 & $\begin{array}{ll}394 & (2 \\
576 & (9 \text { hrs. })\end{array}$ & - & 596 & $422(14,)$, & $\begin{array}{c}\text { Chronic glomeru- } \\
\text { lonephritis }\end{array}$ \\
\hline 23 & 379 (3 days) & 580 & 576 & $498(52,)$, & $\begin{array}{l}\text { Malignant } \\
\text { hypertension }\end{array}$ \\
\hline 24 & $\begin{array}{ll}494 & (3 \\
580 & \text { (1 day) })\end{array}$ & 668 & 682 & $536(13,)$, & $\begin{array}{l}\text { Uraemia due to } \\
\text { polyarteritis } \\
\text { nodosa }\end{array}$ \\
\hline 25 & 440 ( $1 \mathrm{hr})$. & - & - & $440(24,, \quad)$ & Chronic nephritis \\
\hline
\end{tabular}

* Figures in brackets represent time before death.

$\dagger$ Figures in brackets represent time after death. mortem blood levels, when known, were always higher than the corresponding C.S.F. figures.

Correlation is good in every case in spite of the fact that the times between death and the taking of samples of C.S.F. had varied from nine hours to four days, and that the bodies had been stored at different temperatures after death.

In four of the seven cases where blood levels were estimated within a few minutes after death, the levels in the blood taken from the right ventricle of the heart at necropsy, from 13 to 37 hours later, showed an increase of as much as $54 \mathrm{mg}$. per $100 \mathrm{ml}$.

Group 3 : Pre-renal Urea . Retention.-Cases have been placed in this group when on clinical grounds a raised urea level could be attributed to pre-renal causes and where necropsy showed the kidneys to be normal. Cases where both renal and pre-renal factors operated are included in the miscellaneous Group 4.

Nine cases were investigated and the results are shown in Table II. The post-mortem C.S.F. levels varied between 56 and 300 . The wide variation of results is similar to the variation observed in this type of case when investigated during life.

TABLE II

UREA LEVELS (MG. PER 100 ML.) IN PRE-RENAL UREA RETENTION

\begin{tabular}{|c|c|c|c|c|c|}
\hline \multirow[b]{2}{*}{$\begin{array}{l}\text { Case } \\
\text { No }\end{array}$} & \multirow[b]{2}{*}{$\begin{array}{l}\text { Ante- } \\
\text { mortem } \\
\text { Blood }\end{array}$} & \multirow[b]{2}{*}{ 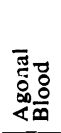 } & \multicolumn{2}{|c|}{ Post-mortem Levels } & \multirow[b]{2}{*}{ Cause of Death } \\
\hline & & & $\frac{7}{0}$ & C.S.F. & \\
\hline 26 & 46 ( 2 days) & - & - & 80 (36 hrs.) & $\begin{array}{l}\text { Paralytic ileus fol- } \\
\text { lowing colostomy } \\
\text { for carcinoma of } \\
\text { rectum }\end{array}$ \\
\hline 27 & 220 (5 hrs. $)$ & - & - & $300(15,)$, & $\begin{array}{l}\text { Perforation at site } \\
\text { of gastroenteros- } \\
\text { tomy; paralytic } \\
\text { ileus }\end{array}$ \\
\hline 28 & 46 (17 days) & - & - & $188(52,)$, & $\begin{array}{l}\text { Paralytic ileus after } \\
\text { transplantation } \\
\text { of ureters }\end{array}$ \\
\hline 29 & $\begin{array}{r}66 \text { (2 . } 19 \text { ) } \\
101 \text { (19 hrs.) }\end{array}$ & 142 & 154 & $114(24, .)$. & $\begin{array}{l}\text { Cardiac failure due } \\
\text { to c or on a ry } \\
\text { atheroma }\end{array}$ \\
\hline 30 & 88 ( 2 days) & - & - & $150(10,)$, & $\begin{array}{l}\text { Cirrhosis of liver; } \\
\text { gross ascites and } \\
\text { oedema }\end{array}$ \\
\hline 31 & 86 (9 hrs.) & 132 & - & $98(17,, \quad)$ & $\begin{array}{l}\text { Carcinoma of lung } \\
\text { with secondaries }\end{array}$ \\
\hline 32 & $53(9,)$, & - & 54 & $56(14,)$, & $\begin{array}{cc}\text { Cardiac } & \text { failure; } \\
\text { mitral stenosis }\end{array}$ \\
\hline 33 & 49 (6 days) & 70 & 82 & $58(15,)$, & $\begin{array}{l}\text { Cardiac failure; } \\
\text { coronary } \\
\text { oma }\end{array}$ \\
\hline 34 & $67(6 \quad)$, & 126 & 140 & $94(24,, \quad)$ & $\begin{array}{l}\text { Hypostatic pneu- } \\
\text { monia; hypoplas- } \\
\text { tic anaemia }\end{array}$ \\
\hline
\end{tabular}


Case 29 shows a terminal rise in blood urea of $41 \mathrm{mg}$. per $100 \mathrm{ml}$. within the last 19 hours of life, and 24 hours after death an even further rise of 12 mg. per $100 \mathrm{ml}$. in the blood, whereas the C.S.F. level is similar to the pre-agonal blood level.

Likewise, Cases 31 and 33 do not show the agonal increase in the post-mortem C.S.F. urea levels which have occurred in the blood. In Case 30 death was due to liver failure, and we should therefore expect to find a normal or low urea level. That a level of 150 was found in the C.S.F. after death is probably explained by the fact that there had been a gross accumulation of fluid in the abdominal cavity necessitating frequently repeated paracenteses before death with resulting severe diversion of fluid from the kidneys, and, therefore, pre-renal urea retention of a moderate degree.

Group 4: Miscellaneous Conditions.-These cases, for various reasons, do not fit into any of the preceding groups. The results are shown in Table III.

TABLE III

MISCELLANEOUS CASES

\begin{tabular}{|c|c|c|c|c|c|}
\hline \multirow[b]{2}{*}{$\begin{array}{l}\text { Case } \\
\text { No. }\end{array}$} & \multirow{2}{*}{$\begin{array}{c}\text { Ante- } \\
\text { mortem* } \\
\text { Blood }\end{array}$} & \multirow[b]{2}{*}{ 覀: } & \multicolumn{2}{|c|}{ Post-mortem Levels } & \multirow[b]{2}{*}{ Cause of Death } \\
\hline & & & $\frac{\overrightarrow{0}}{0}$ & C.S.F. & \\
\hline 35 & 40 ( 2 days) & - & 28 & $28(10$ hrs. $)$ & $\begin{array}{l}\text { Haemochromatosis; } \\
\text { liver failure }\end{array}$ \\
\hline 36 & 136 (1 day) & - & 144 & $151(14,)$, & $\begin{array}{l}\text { Diabetic coma; be- } \\
\text { nign hypertensive } \\
\text { changes in kid- } \\
\text { neys }\end{array}$ \\
\hline 37 & $73(1,)$, & - & - & $132(12,)$, & $\begin{array}{l}\text { Pulmonary embo!- } \\
\text { ism; chronic pye- } \\
\text { lonephritis and } \\
\text { hypertension }\end{array}$ \\
\hline 38 & $\begin{array}{l}135 \text { (10 days) } \\
137 \text { (1 day) } \\
134 \text { (5 hrs.) }\end{array}$ & 170 & $\overline{\overline{1}}$ & $\begin{array}{l}132(24,, \quad) \\
142(48, ") \\
120(72,,)\end{array}$ & $\begin{array}{l}\text { Cerebellar haemor- } \\
\text { rhage; diabetic } \\
\text { glomerulosclero- } \\
\text { sis and hyper- } \\
\text { tension }\end{array}$ \\
\hline
\end{tabular}

* Urea levels expressed as $\mathrm{mg}$. per $100 \mathrm{ml}$.

Case 35 is one of liver failure showing a drop in urea level from 40 in the blood two days before death to 28 in the blood and C.S.F. 10 hours after death.

Case 36 is considered to be one of extra-renal uraemia in a man dying in diabetic coma. The case could not be placed in Group 3, however, because mild benign hypertensive changes were found in the kidneys histologically. There is no evidence of diabetic glomerulosclerosis.

Cases 37 and 38 showed a severe degree of renal damage with evidence, during life, of kidney failure. The progress of the kidney disease in each instance was terminated unexpectedly by death $\overline{0}$ from pulmonary embolism in the former and by cerebellar haemorrhage in the latter. The post- $\frac{0}{9}$ mortem C.S.F. urea levels record, fairly accurately, the degree of renal failute existing before death. $\frac{\partial}{=}$ In Case 38 it was possible to follow urea levels in $\frac{5}{\sigma}$ the blood right up to the time of death. An agonal $\stackrel{\mathbb{Q}}{\circ}$ rise of nearly $40 \mathrm{mg}$. per $100 \mathrm{ml}$. occurred in the blood within the last five hours of life. There was also a rise in the urea content in the blood after? death amounting to $28 \mathrm{mg}$. per $100 \mathrm{ml}$. in 72 hours. $\vec{\omega}$ However, the C.S.F. urea levels after death bear $\stackrel{\circ}{\circ}$ close relation to those found in the blood during life before the agonal rise took effect. The small os differences in the daily post-mortem C.S.F. urea ? levels arose because the first two specimens $\vec{\overrightarrow{ }}$ obtained by cisternal puncture were contaminated with blood, whereas the third specimen procured $\mathrm{I}$ directly from the infundibulum was not so contaminated.

\section{Discussion}

Urea is an easily diffusible non-electrolyte (Eggleton, 1930 ; Folin and Berglund, 1922) and is thus found in fairly uniform concentration in most tissues and fluids of the body during life.

Studies on the C.S.F. and aqueous humour of the eye led Walker (1933) to the conclusion that $\stackrel{\circ}{D}$ the choroidal and ciliary epithelia exhibit selective $\cong$ qualities with regard to urea and that neither the C.S.F. nor the aqueous humour urea levels are controlled by a simple process of filtration. On the other hand, Fremont-Smith, Dailey, Merritt, Carroll, and Thomas (1931) found the C.S.F. to be in osmotic equilibrium with the plasma, but state that after any change in the blood 3 . there is a latent period of perhaps many hours $\delta$ before the C.S.F. regains equilibrium. Many other $₹$ investigators who uphold this diffusion theory 응 (Myers and Fine, 1919 ; Cullen and Ellis, 1915) agree that there is a considerable lag in the attainment of equilibrium after a change in the plasma content.

During the moribund state, when the renal N circulation is failing, with consequent urea reten- N tion, it is conceivable that a simultaneous failure $O$ of the circulation in the choroidal plexus prevents the raised blood level being "transmitted" to the C.S.F.

On three occasions specimens of blood were obtained within a matter of hours before death followed by a further specimen taken within the $\overrightarrow{\mathbb{D}}$ first few minutes after death in the same patient. $\mathbb{D}$ The ante-mortem values of 490,86 , and $134 \mathrm{mg}$. per $100 \mathrm{ml}$. rose to 560,132 , and $170 \mathrm{mg}$. per 100 ml. respectively at death. The post-mortem C.S.F. 
values of 570,98 , and 120 did not show the agonal rise in two cases.

Increases in the blood urea levels were found to occur between the time of death and the time of necropsy in seven cases. They ranged from $2 \%$ to $22 \%$ of the blood levels at death, but bore no quantitative relationship to the time after death at which they were estimated or to the degree of urea retention existing at the time of death. Such increases might be due to continued urea production by the liver after death or to the formation of ammonia (which is included as urea in the test) from protein breakdown by enzyme or bacterial activity.

The post-mortem C.S.F. urea levels in these cases were the same as, or somewhat lower than, the blood levels at death. It is therefore suggested that the C.S.F. is shielded by its secluded situation from the post-mortem increases of urea in the blood. The post-mortem C.S.F. urea level can therefore be taken as a reliable guide of the state of ante-mortem urea retenticn in the phase of the illness immediately preceding the moribund state, provided the latter state is not very prolonged.

Even where the blood or C.S.F. figures at necropsy have shown a change from the pre-agonal blood level, the differences have been so small in this series that not once would they have misled the pathologist in his interpretation of the case.

The values in the renal failure group have a much higher average than those in the pre-renal urea retention group, but there is such a marked overlap that the segregation of cases into one or other of these groups on post-mortem urea levels alone cannot be recommended. Naumann (1949) has shown that when a high post-mortem C.S.F. urea level is found in the absence of comparable kidney disease a post-mortem urinary analysis will often help to rule out renal causes. In such cases, one of the several causes of pre-renal azotaemia should be found.

In 10 cases in this series urea retention had no bearing on the cause of death, as judged by both the clinician and pathologist. These cases gave much lower post-mortem C.S.F. urea levels, varying from normal to 151, with an average of 64 .

This investigation suggests that a normal C.S.F. urea level found at necropsy will rule out uraemia as a cause of death.

Allen (1951), quoting from the work of Naumann, agrees that the C.S.F. appears more dependable than the blood for urea determinations but remarks that the former is not so easily secured. No such difficulty was encountered in this investigation, but a further advantage is that the C.S.F. is still readily available towards the end of a postmortem examination, when other findings may have led one to consider uraemia as a cause of death.

\section{Summary}

Post-mortem C.S.F. urea levels at varying periods after death were found to correlate closely with ante-mortem blood levels and with the clinical and pathological features of the case.

The post-mortem blood levels, though agreeing fairly well with the ante-mortem blood levels, were found to be less reliable than those of the C.S.F.

No anomalous results were found in a series of 38 cases.

I wish to thank Professor J. Gough for his interest and advice in the preparation of this paper, and Mr. T. V. Berry for performing many of the urea estimations.

\section{REFERENCES}

Allen, A. C. (1951). The Kidney, p. 76. Grune and Stratton, New York.

Cullen, G. E. and Ellis, A. W. M. (1915). J. biol. Chem., $20,511$.

Eggleton, P. (1930). J. Physiol., Lond., 70, 294.

Egglin, O., and Berglund. H. (1922). J. biol. Chem., 51, 395

Folin, O., and Berglund, H. (1922). M. biol. Chem., 51, 395. and Thomas, G. W. (1931). Arch. Neurol. Psychiat., Chicago, 25,1271 .

Hamilton, R. C. (1938). Arch. Path., Chicago, 26, 1135.

Harrison, G. A. (1947). Chemical Methods in Clinical Medicine, 3rd ed., p. 99 . Churchill, London.

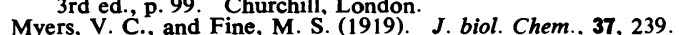

Myers, V. C., and (1949). Arch. Path., Chicago, 47, 70.

(1950). Amer. J. clin. Path., 20, 314.

Polayes, S. H., Hershey, E., and Lederer, M. (1930). Arch. intern. Med., 46, 283.

Tarsitano, F. (1950). Folia med., Napoli, 33, 310

Walker, A. M. (1933). J. biol. Chem., 101, 269. 